\title{
Statistical Analysis of Causes of Death (2005-2010) in Villages of Simav Plain, Turkey, With High Arsenic Levels in Drinking Water Supplies
}

\author{
ORHAN GUNDUZ ${ }^{1}$, COSKUN BAKAR ${ }^{2}$, CELALETTIN SIMSEK ${ }^{3}$, ALPER BABA $^{4}$, ALPER ELCI $^{1}$, HAKAN $^{2}$ \\ GURLEYUK ${ }^{5}$, MERDIYE MUTLU ${ }^{6}$, and AYSE CAKIR ${ }^{6}$ \\ ${ }^{1}$ Department of Environmental Engineering, School of Engineering, Dokuz Eylul University, Izmir, Turkey \\ ${ }^{2}$ Department of Public Health, School of Medicine, Canakkale Onsekiz Mart University, Canakkale, Turkey \\ ${ }^{3}$ Department of Drilling, Torbali Vocational School, Dokuz Eylul University, Izmir, Turkey \\ ${ }^{4}$ Department of Civil Engineering, School of Engineering, Izmir Institute of Technology, Izmir, Turkey \\ ${ }^{5}$ Applied Speciation and Consulting LLC, Bothell, Washington, USA \\ ${ }^{6}$ Graduate School of Natural and Applied Sciences, Dokuz Eylul University, Izmir, Turkey
}

Received 8 March 2013, Accepted 8 November 2013

\begin{abstract}
The purpose of this research was to compare the causes of death in 5 villages situated in Simav Plain, Turkey, during 2005-2010 where different arsenic levels were detected in drinking water supplies. Since groundwater in Simav Plain had arsenic concentrations that ranged between 7.1 and $833.9 \mathrm{ppb}$, a two-phase research was formulated. In the first phase, public health surveys were conducted with 1,003 villagers to determine the distribution of diseases. In the second phase, verbal autopsy surveys and official death records were used to investigate the causes of death. In total, 402 death cases were found in the study area where cardiovascular system diseases $(44 \%)$ and cancers $(15.2 \%)$ were major causes. Cancers of lung $(44.3 \%)$, prostate $(9.8 \%)$, colon $(9.8 \%)$, and stomach $(8.2 \%)$ were comparably higher in villages with high arsenic levels in drinking water supplies. Furthermore, the majority of cases of liver, bladder, and stomach cancers were observed in villages with high arsenic levels.
\end{abstract}

Keywords: arsenic, groundwater, public health, Simav, Turkey, verbal autopsy

Arsenic in drinking water is considered to be a carcinogen by the World Health Organization (WHO), and chronic arsenic exposure is known to cause cancers of skin, bladder, lung, liver, and stomach. ${ }^{1,2}$ In addition, arsenic is also considered to be among the etiological characteristics of many chronic illnesses, such as cardiovascular diseases, diabetes mellitus, and others. ${ }^{1-8}$ In accordance with the research that proves the link between arsenic and lethal diseases, the arsenic standard value in drinking water was reduced to $10 \mathrm{ppb}$ level in many countries. $^{9-11}$

The arsenic problem in groundwater in Kütahya, Turkey, has been reported in previous studies. ${ }^{12-14}$ Doğan et al ${ }^{12}$ has documented the presence of skin lesions in the inhabitants of Emet District of Kütahya Province due to high arsenic exposure through dermal track. Gunduz et al, ${ }^{13}$ on the other hand, have determined the arsenic pollution in groundwater

Address correspondence to Orhan Gunduz, Department of Environmental Engineering, Dokuz Eylul University, Tinaztepe Campus, Buca, Izmir 35160, Turkey. E-mail: orhan.gunduz@, deu.edu.tr

Color versions of one or more of the figures in the article can be found online at www.tandfonline.com/vaeh. of Simav Plain, a graben area near Simav District of Kütahya Province. The region is situated in an area of active tectonism, with the presence of alteration zones and geothermal resources. An average arsenic concentration of $99 \mathrm{ppb}$ was detected by Gunduz et al, ${ }^{13}$ where maximum levels reached 561 ppb. In the same study, 221 cases of death between 1998 and 2005 were analyzed, and cardiovascular diseases $(45.2 \%)$ were found to be the primary cause of death, followed by cancers $(15.8 \%)$ and respiratory system illnesses (5.7\%). Among all neoplasms, lung cancers were the most predominant $(34.1 \%)$ cancer type, which was followed by stomach $(20 \%)$, colon and prostate $(20 \%)$, and liver $(17.1 \%)$ cancers.

Although there is substantial amount of information present on elevated arsenic occurrences for many parts of Turkey, literature on health problems associated with arsenic exposure is limited to the study of Doğan et al, ${ }^{12}$ where they discussed the skin cancer occurrences of arsenic-exposed population from Emet District of Kütahya Province. Nevertheless, no research has been conducted so far on the occurrence of systemic diseases with arsenic exposure. Thus, this study is conducted in an area where a moderately long-term exposure to arsenic was experienced. The study area included 3 villages (Çitgöl, Boğazköy, and Gölköy) of Simav District with 
above-standard arsenic levels in drinking water supplies where minimum 20 years of exposure took place. Such a longterm exposure to high arsenic-containing drinking water was believed to create human health implications with regards to systematic diseases. Based on this premise, this research was conducted in the villages of Çitgöl, Gölköy, Boğazköy, Öreyler, and Demirciköy to determine the causes of death during the 2005-2010 period through a verbal autopsy survey and compilation of official records and to demonstrate the relationship between high arsenic exposure and causes of death in the area.

\section{Methods}

\section{Study Area}

The study area of this research is the Simav Plain situated in Western Anatolia, Turkey (Figure 1). Simav Plain is a graben depression with complex geology and active tectonics. Previous research conducted in the study area has revealed the presence of elevated levels of arsenic in surface and subsurface waters of the plain. ${ }^{13,15}$ Further research in the area has revealed the fact that the alluvial material that forms the groundwater containing aquifer in the plain was extremely rich in arsenic. The results of the geochemical investigations conducted at 21 boreholes that were drilled throughout the plain has shown that arsenic in Simav Plain alluvial layer ranged between 7.1 and $833.9 \mathrm{ppb}$, with an average of $48.99 \mathrm{ppb}$ and a standard deviation of $80.21 \mathrm{ppb}{ }^{16}$ When compared with the average value of $1.5 \mathrm{ppm}$ arsenic in world soils, ${ }^{17}$ it was clear that the study area was a hot spot and had elevated risks associated with human exposure to arsenic. In addition, further monitoring studies verified the above-average arsenic occurrences in the groundwater of the alluvial plain based on the results of wet and dry season sampling programs completed during April and September 2011. ${ }^{16}$ Accordingly, the arsenic levels in groundwater ranged between 1 and $1025.6 \mathrm{ppb}$ with an average of $234.9 \mathrm{ppb}$ and a standard deviation of $261.8 \mathrm{ppb}$ during April 2011 monitoring program, and between $1.3 \mathrm{ppb}$ and $1123.7 \mathrm{ppb}$ with an average of $256.2 \mathrm{ppb}$ and a standard deviation of $288.9 \mathrm{ppb}$ during September 2011 monitoring program. ${ }^{16}$ The time-series results of arsenic in the water supplies of the 5 villages are given in Table 1. From a public health point of view, this information was sufficient to initiate further studies to understand the potential health implications of this elevated arsenic presence in the plain's groundwater that was used for domestic and irrigational water supplies.

\section{Research Approach}

The main objective of this study was to compare the causes of death in villages with high levels of arsenic and with belowstandard levels of arsenic in their drinking water supplies. Considering the general deficiencies in collecting the data for causes of death in rural areas, different methods of data collection were used to overcome the problems associated with data availability. One of the methods used was a verbal autopsy survey conducted by a medical doctor who was also a public health specialist to query the presence of deaths in the village within the last 5 years by questioning relatives of the deceased and to assess the main cause of death. However, this method was insufficient to reach all cases of death, and information regarding the remaining cases was obtained from official records. Unfortunately, some of these records (obtained from the records of public health centers, municipalities, and civil registration and nationality offices) were also deficient in the study area. Despite the deficiencies, the available official death records were also analyzed and when a definitive cause of death was not written, the relatives of these death cases were questioned with the verbal autopsy survey. All the data collected from these methods were assessed together and were cross-checked with the causes of death of a few cases available in hospital records to evaluate the overall accuracy of the verbal autopsy surveys.

\section{Population and Sample Size}

The population of this study was composed of all inhabitants of the villages of Gölköy, Boğazköy, Çitgöl, Öreyler, and Demirciköy with an age of 18 and above (Figure 1). The total population of the 5 villages studied was 6,879 in the year 2009 , of which $47.9 \%(3,292)$ were male and $52.1 \%(3,587)$ were female. About $17.2 \%$ of the total population was above the age of 65. Based on the records of the Civil Registration and Nationality Office of the District of Simav, a total of 5,178 people (18+ population) lived in these 5 villages in the year 2009. Of this total, 3,264 individuals lived in 3 villages (Boğazköy, Gölköy, and Çitgöl) where drinking water supplies contained above-standard arsenic levels and the remaining 1,914 individuals lived in 2 villages (Demirciköy and Öreyler) with below-standard level of arsenic in drinking water supplies. The number of individuals aimed to be reached in each group of villages (sampling size) was computed separately according to the following formula given by Lemeshow et $\mathrm{al}^{18}$ :

$$
n=\frac{N\left(Z_{1-\alpha / 2}^{2} P(1-P)\right)}{d^{2}(N-1)+Z_{1-\alpha / 2}^{2} P(1-P)}
$$

where $n$ is the sample size, $N$ is population size, $Z_{1-\alpha / 2}$ is the number of standard errors from the mean (1.96), $P$ is the anticipated population proportion (0.5), and $d$ is the absolute precision required on either side of the proportion (0.05). Accordingly, the minimum sample sizes to be reached by the field teams were found to be 344 for the villages with high arsenic in drinking water and 321 for the villages with low arsenic in drinking water. Based on these minimum numbers, the household survey was conducted with a total of 1,003 people, of which 614 lived in villages with high arsenic level and 389 lived in villages with low arsenic level in drinking water supplies.

\section{Implementation Details}

The verbal autopsy survey was held in 3 phases during the first 2 weeks of June 2010 and June 2011. The first phase was conducted simultaneously with the household survey. In this 


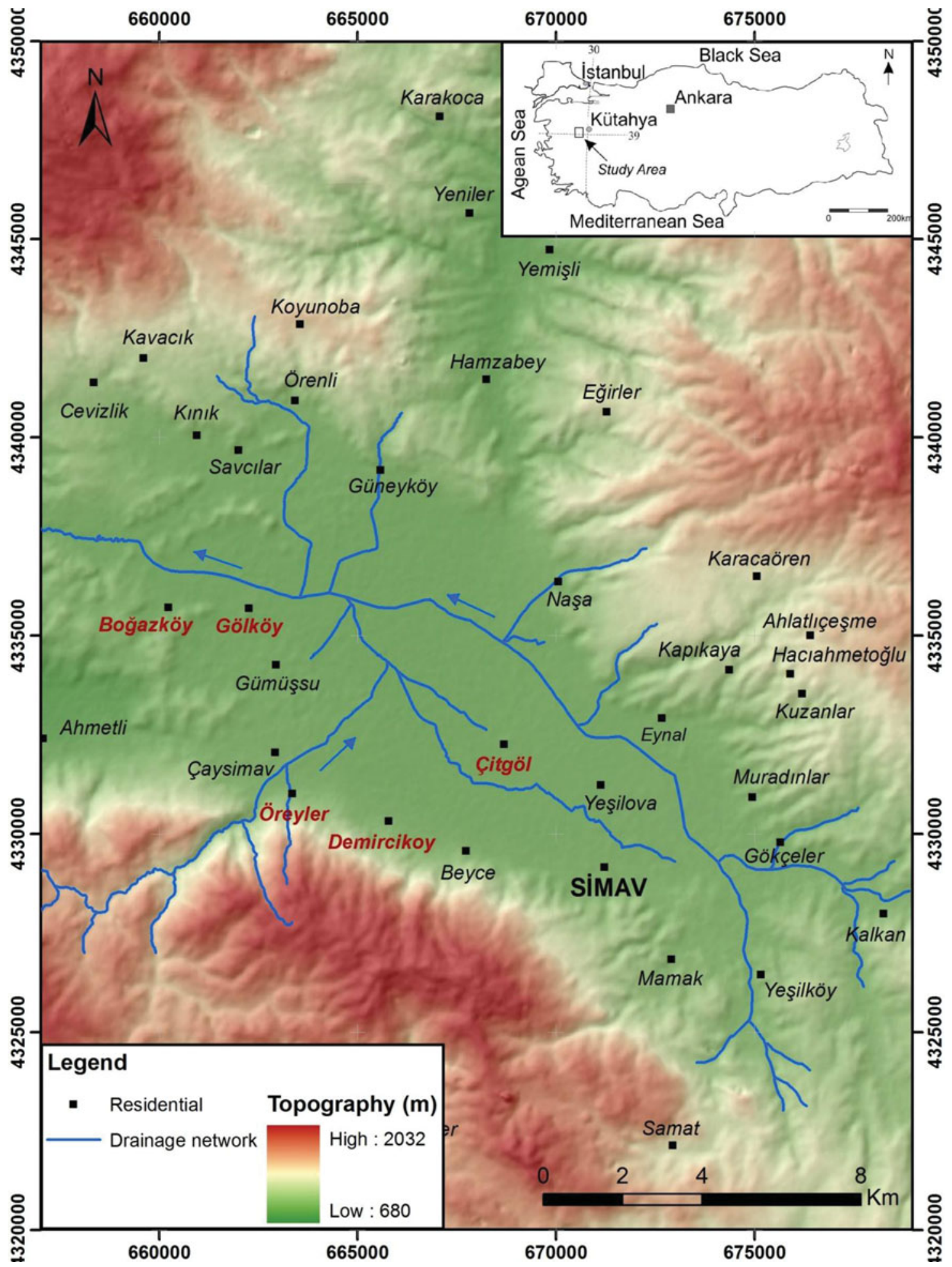

Fig. 1. The study area.

phase, household questionnaire forms were filled by questioning individuals from randomly selected houses until a predetermined sampling size was reached in each village. In all 5 villages, the minimum sampling size was exceeded to better characterize the settlements. The questionnaires were implemented by a group of trained surveyors and were conducted through face-to-face interviews. During questionnaires, the individual was asked if he could recall any incidences of death in his family or in the village during 2005-2010 period. Death cases determined from this questioning were then reported to the medical doctor, who was also a public health specialist so that he then could conduct the verbal autopsy survey with the 
Table 1. Arsenic Concentrations (ppb) in the Drinking Water Supplies of the Villages Studied, 2011, Simav-Kütahya

\begin{tabular}{|c|c|c|c|c|}
\hline \multirow[b]{2}{*}{ Village } & \multicolumn{4}{|c|}{ As $(\mathrm{ppb})^{* * * *}$} \\
\hline & July $2005^{12}$ & May $2010^{15}$ & April $2011^{15}$ & September $2011^{15}$ \\
\hline Demirciköy & No data & 1.3 & 1.3 & 1.3 \\
\hline Öreyler & No data & 1.0 & Not sampled & Not sampled \\
\hline Çitgöl & 27.0 & 42.9 & 37.2 & 64.4 \\
\hline Gölköy-Boğazköy* & No data & No data & 318.2 & 331.4 \\
\hline Gölköy-Boğazköy** & 177.2 & 1812.8 & 876.3 & 605.0 \\
\hline Gölköy-Boğazköy*** & No data & 9.2 & Not sampled & Not sampled \\
\hline
\end{tabular}

*Previously used spring: Gölköy and Boğazköy villages have used water from this spring during 1984-1997 period.

** Previously used well: Gölköy and Bogazköy villages have used water from this borehole during 1997-2008 period. The well is not used since 2009.

***New well: Gölköy and Boğazköy villages are currently using the water extracted from this new well since July 2009.

****The arsenic measurements were made with inductively coupled plasma mass spectrometer (ICP-MS) technique.

relatives of the deceased. The specialist then conducted the verbal autopsy survey to the closest relative of the deceased who was beside the deceased during his final hours in order to obtain information regarding the cause of death. All verbal autopsies were conducted by the same expert to eliminate the risk of differences in personal interpretations. The total number of verbal autopsy surveys conducted was 29 (70.7\% of all deaths) in Gölköy, 47 (92.2\% of all deaths) in Boğazköy, 33 (22\% of all deaths) in Çitgöl, 40 (57.1\% of all deaths) in Öreyler, and 22 (24.4\% of all deaths) in Demirciköy, which summed to a total of 171 surveys in the study area.

The second phase of the study was based on official death records. All cases of death during 2005-2010 period were obtained from Family Health Center in Gölköy and Boğazköy; from municipality death records in Demirciköy; and from Civil Registration and Nationality Office of the District of Simav in Öreyler and Çitgöl. These records were used not only to fill in the missing records of death that could not be reached during verbal autopsy surveys but also to verify causes of death that were identified in the surveys.

In the third phase, the accuracy of the cause of death information obtained from verbal autopsies and official records were verified by the records of Simav Hospital. The death documents of 22 people who died in the hospital were requested from the hospital administration. The hospital provided information regarding 15 of the 22 cases of death. Subsequently, the causes of death in hospital records were compared with the information obtained from verbal autopsy surveys to judge the overall performance of verbal autopsy survey procedure in the study area.

\section{Survey Form}

The verbal autopsy survey form used in this study was developed by the World Health Organization and was previously used in National Burden of Disease and Cost Effectiveness Project. ${ }^{19}$ The survey was composed of 3 sections and mostly contained closed-ended questions. The first section contained questions for cases of death that occurred with ages 5 and above. The second section contained questions regarding infant deaths that occurred between 0 and 28 days. The final section was designed to question cases of child death that occurred between 29 days and 5 years of age. The main objective of the form was to determine the cause of death through questioning the suffered disease(s) and its characteristic signs and symptoms prior to death. ${ }^{19}$

After completion of the verbal autopsy survey, questions regarding the primary cause of death and final cause of death were asked and assessed together to determine the actual cause of death for the particular case. Cardiac arrest, respiratory arrest, cardiogenic shock, etc, were accepted to be the final cause of death and were not considered to be primary cause of death.

\section{Statistical Analysis}

Upon completion of data control and correction, the results of the study were analyzed with the Statistical Package for the Social Sciences (SPSS) program (SPSS ver. 15, Chicago, IL, USA). Chi-square goodness-of-fit, Student's $t$ test, and variance analysis were used in statistical analysis of the data. It was assumed that $p<.05$ for all statistical analysis. The International Classification of Diseases (ICD-10) coding system that was offered by WHO in grouping disease symptoms and cause of death was used in this study.

Crude mortality rate, cancer-specific crude mortality rate, and age-standardized mortality rate were calculated and used in the analysis of death data. Crude mortality rate calculations were done annually using the population and number of deaths in 2009. Cancer-specific crude mortality rates were calculated for 2005-2010 period and were done using agestandardized mortality rates that were calculated based on world standard population. Age-standardized mortality rates that demonstrate the number of new cases of death per 100,000 people per year is a rate measure that a population would have if it had a standard age structure. Standardization is necessary when comparing several populations that differ with respect to age, since age has a powerful influence on cancer risk.

\section{Results}

A total of 402 cases of death were determined in 5 villages during 2005-2010 period. Of this total, 171 cases were determined 
Table 2. Distribution of Age of Death With Respect to Sex in Villages Studied, Kütahya-Simav, 2011

\begin{tabular}{|c|c|c|c|c|c|c|c|c|c|c|c|c|c|}
\hline \multirow[b]{2}{*}{ Village } & \multicolumn{4}{|c|}{ Female } & \multicolumn{4}{|c|}{ Male } & \multicolumn{4}{|c|}{ Total } & \multirow[b]{2}{*}{$p^{*}$} \\
\hline & $n$ & $\% a$ & Mean & $S D$ & $n$ & $\%{ }^{a}$ & Mean & $S D$ & $n$ & $\% 0^{b}$ & Mean & $S D$ & \\
\hline Gölköy & 18 & 43.9 & 76.7 & 14.7 & 23 & 56.1 & 75.6 & 11.6 & 41 & 10.2 & 76.1 & 12.9 & .5490 \\
\hline Boğazköy & 18 & 35.3 & 73.1 & 11.5 & 33 & 64.7 & 76.3 & 14.1 & 51 & 12.7 & 75.2 & 13.2 & .1760 \\
\hline Öreyler & 39 & 55.7 & 77.5 & 16.1 & 31 & 44.3 & 68.9 & 20.1 & 70 & 17.4 & 73.7 & 18.3 & .1150 \\
\hline Demirciköy & 40 & 44.4 & 80.9 & 8.9 & 50 & 55.6 & 69.8 & 17.5 & 90 & 22.4 & 74.7 & 15.2 & .0001 \\
\hline Çitgöl & 74 & 49.3 & 71.5 & 23.1 & 76 & 50.7 & 65.3 & 18.5 & 150 & 37.3 & 67.5 & 20.2 & .3080 \\
\hline Total & 189 & 47.0 & 77.0 & 14.7 & 213 & 53.0 & 70.9 & 17.0 & 402 & 100.0 & 73.5 & 16.3 & $.0020^{* *}$ \\
\hline
\end{tabular}

${ }^{a}$ Row percentage.

${ }^{b}$ Column percentage.

*Mann-Whitney $U$ test.

** Student's $t$ test goodness of fit of difference between 2 averages.

via verbal autopsy survey and the remaining 231 cases were extracted from official records. Official death records were also accessed for 121 of 171 cases to which verbal autopsy were made. The average age of death was $73.5 \pm 16.5 ; 53 \%$ of the deceased were male and $47 \%$ were female. The average age of death was $77.0 \pm 14.7$ and $70.9 \pm 17.0$ for females and males, respectively. Statistically significant $(p<.05)$ differences were detected between the ages of death of 2 sexes (Table 2). The average crude mortality rate in the study area for the year 2009 was calculated as $8.3 \%$. Specifically, the mortality rates were found to be higher in Gölköy (18.6\% ) and Boğazköy (19.7\%) and comparably low in Çitgöl $(5.6 \%)$, Demirciköy $(7.7 \%)$, and Öreyler $(9.3 \% 0)$. As expected, the average age of death was found to be higher in women. The crude mortality rate in the study area was calculated to be $8.3 \%$, which was higher than the national value of $6.3 \%$ of year $2008 .{ }^{20}$ This difference between crude mortality rates was an expected outcome, since the total population of age 65 and above was higher in the study area $(17.2 \%)$ when compared with the national average $(7.2 \%)$.

Of all death cases during 2005-2010 period that were detected in the verbal autopsy survey, $70.2 \%$ occurred in the residence and $24.6 \%$ occurred in the hospital, whereas the remaining cases $(5.4 \%)$ occurred in the field or orchard. Twentytwo of the total 42 cases that occurred in the hospital was in Simav State Hospital. The records of 15 of these cases were obtained from the hospital, and the cause of death determined from the verbal autopsy was verified with the cause of death stated in hospital records in 12 of the cases $(80 \%)$. Two infant deaths at 2 and 9 months occurred in Çitgöl. One of these deaths was related to respiratory distress of newborn (P22), and the other occurred due to spina bifida (Q05). One child death occurred at the age of 7 in Demirciköy and was related to drowning and submersion while in natural water (W69). Apart from these 3,81.1\% of all other cases of death occurred at an age 65 or higher and $17.8 \%$ occurred between ages of 20 and 65. No statistically significant $(p>.05)$ differences were detected between the ages of death among the villages.

No significant differences $(p>.05)$ were detected between the distributions of cigarette, alcohol, and drug use of all cases of death that were detected through verbal autopsy survey. Rates of cigarette and alcohol use were found to be $29.8 \%$ and
$9.4 \%$, respectively. Only 1 case of death related to drug use was detected in the village of Öreyler. This individual died at the age of 35 , and the determined cause of death was related to mental and behavioral disorders due to multiple drug use and use of other psychoactive substances (F19).

The primary cause of death identified in this study was the diseases of the circulatory system (44\%). In this group of diseases, cardiac insufficiency (24.4\%), cerebrovascular disease $(8.2 \%)$, essential hypertension $(5.2 \%)$, and acute myocardial infarction $(5.0 \%)$ were the top 4 commonly observed causes of death in the study area. Excluding the category symptoms, signs, and abnormal clinical and laboratory findings (not elsewhere classified), cancers $(15.4 \%)$ and diseases of the respiratory system $(5.7 \%)$ rank the second and third most common causes of death in the area, as seen from Table 3 and shown in Figure 2. No cases of stillbirth or maternal mortality were recorded in the study area during 2005-2010 period.

In general, lung cancer was found to be the most predominant cancer type that resulted in deaths in this study, which was followed by prostate and colon cancers. The cancerrelated mortality rates were found to be $177.4 / 100,000$ as crude mortality rate and 104/100,000 as age-standardized mortality rate calculated based on standard world population. Age-standardized cancer mortality rate was $117.6 / 100,000$ for villages with high arsenic levels and 83.5/100,000 for villages with below-standard arsenic levels. When cancer-related deaths are analyzed, it was observed that cases of stomach liver and bladder cancers were reported from villages that had high arsenic levels.

A total of $39.4 \%$ of all cancer-related deaths had a definite history of cigarette smoking. In an additional $31.1 \%$ of all cancer-related deaths, cigarette use could not be identified clearly. Furthermore, it has been found that there is a definite history of cigarette smoking in 51.8\% (14 cases) of all lung cancer-related deaths and a skeptical history in an additional $29.6 \%$ ( 8 cases). Statistically significant relevance $(p<.05)$ has been detected between cigarette smoking and cancer related deaths. Whereas $36.4 \%$ of cigarette smokers died as a result of cancer, only $17.1 \%$ of nonsmokers died from cancers. Statistically significant differences $(p<.05)$ were found between cigarette smoking and cancer occurrences. Furthermore, lung cancer was found to be the cause of death in $21.2 \%$ of all 
Table 3. Distribution of Primary Cause of Death in Villages Studied, 2011, Simav-Kütahya

\begin{tabular}{|c|c|c|c|c|c|c|c|c|c|c|c|c|c|}
\hline \multirow[b]{2}{*}{ ICD-10 code } & \multirow[b]{2}{*}{ Disease group } & \multicolumn{2}{|c|}{ Total } & \multicolumn{2}{|c|}{ Gölköy } & \multicolumn{2}{|c|}{ Boğazköy } & \multicolumn{2}{|c|}{ Öreyler } & \multicolumn{2}{|c|}{ Demirciköy } & \multicolumn{2}{|c|}{ Çitgöl } \\
\hline & & $n$ & $\%$ & $n$ & $\%$ & $n$ & $\%$ & $n$ & $\%$ & $n$ & $\%$ & $n$ & $\%$ \\
\hline A00-B99 & $\begin{array}{l}\text { Certain infectious and parasitic } \\
\text { diseases }\end{array}$ & 1 & 0.2 & 0 & 0.0 & 0 & 0.0 & 0 & 0.0 & 0 & 0.0 & 1 & 0.7 \\
\hline C00-D48 & Neoplasms (cancers) & 61 & 15.2 & 8 & 19.5 & 12 & 23.5 & 12 & 17.1 & 8 & 8.9 & 21 & 14.0 \\
\hline E00-E90 & $\begin{array}{l}\text { Endocrine, nutritional and } \\
\text { metabolic diseases }\end{array}$ & 13 & 3.2 & 3 & 7.3 & 7 & 13.7 & 1 & 1.4 & 1 & 1.1 & 1 & 0.7 \\
\hline F00-F99 & Mental and behavioral disorders & 1 & 0.2 & 0 & 0.0 & 0 & 0.0 & 1 & 1.4 & 0 & 0.0 & 0 & 0.0 \\
\hline G00-G99 & Diseases of the nervous system & 5 & 1.2 & 0 & 0.0 & 0 & 0.0 & 5 & 7.1 & 0 & 0.0 & 0 & 0.0 \\
\hline I00-I99 & $\begin{array}{l}\text { Diseases of the circulatory } \\
\text { system }\end{array}$ & 177 & 44.0 & 21 & 51.2 & 19 & 37.3 & 29 & 41.4 & 63 & 70.0 & 45 & 30.0 \\
\hline J00-J99 & $\begin{array}{l}\text { Diseases of the respiratory } \\
\text { system }\end{array}$ & 23 & 5.7 & 3 & 7.3 & 2 & 3.9 & 8 & 11.4 & 3 & 3.3 & 7 & 4.7 \\
\hline K00-K93 & Diseases of the digestive system & 8 & 2.0 & 0 & 0.0 & 3 & 5.9 & 2 & 2.9 & 2 & 2.2 & 1 & 0.7 \\
\hline M00-M99 & $\begin{array}{l}\text { Diseases of the musculoskeletal } \\
\text { system and connective tissue }\end{array}$ & 2 & 0.5 & 0 & 0.0 & 1 & 2.0 & 0 & 0.0 & 0 & 0.0 & 1 & 0.7 \\
\hline N00-N99 & $\begin{array}{l}\text { Diseases of the genitourinary } \\
\text { system }\end{array}$ & 7 & 1.7 & 0 & 0.0 & 1 & 2.0 & 0 & 0.0 & 3 & 3.3 & 3 & 2.0 \\
\hline P00-P96 & $\begin{array}{l}\text { Certain conditions originating } \\
\text { in the prenatal period }\end{array}$ & 1 & 0.2 & 0 & 0.0 & 0 & 0.0 & 0 & 0.0 & 0 & 0.0 & 1 & 0.7 \\
\hline Q00-Q99 & $\begin{array}{l}\text { Congenital malformations, } \\
\text { deformations and } \\
\text { chromosomal abnormalities }\end{array}$ & 1 & 0.2 & 0 & 0.0 & 0 & 0.0 & 0 & 0.0 & 0 & 0.0 & 1 & 0.7 \\
\hline R00-R99 & $\begin{array}{l}\text { Symptoms, signs and abnormal } \\
\text { clinical and laboratory } \\
\text { findings, not elsewhere } \\
\text { classified }\end{array}$ & 88 & 21.9 & 6 & 14.6 & 3 & 5.9 & 8 & 11.4 & 6 & 6.7 & 65 & 43.3 \\
\hline \multirow[t]{2}{*}{ S00-T98 } & $\begin{array}{l}\text { Injury, poisoning and certain } \\
\text { other consequences of } \\
\text { external causes }\end{array}$ & 14 & 3.5 & 0 & 0.0 & 3 & 5.9 & 4 & 5.7 & 4 & 4.4 & 3 & 2.0 \\
\hline & Total & 402 & 100.0 & 41 & 100.0 & 51 & 100.0 & 70 & 100.0 & 90 & 100.0 & 150 & 100.0 \\
\hline
\end{tabular}

smokers and only $4.8 \%$ of nonsmokers. On the other hand, no statistically significant differences $(p>.05)$ were detected between cancer-related deaths and alcohol use.

When causes of death were grouped as cardiovascular diseases, diabetes mellitus, cancers, and all other causes, it was found that statistically significant differences $(p<.05)$ were detected between the 2 groups of villages with different arsenic levels in their drinking water supplies. In villages with high arsenic levels in drinking water supplies, $39.6 \%$ of all deaths were related to cardiovascular diseases and diabetes mellitus, $16.9 \%$ was related to cancers, and $43.5 \%$ were related to other causes. On the other hand, in villages with below standard arsenic levels in drinking water supplies, $58.8 \%$ of all deaths were related to cardiovascular diseases and diabetes mellitus, $12.5 \%$ were related to cancers, and $28.7 \%$ were related to other causes. It has been further found that cancers were observed in higher numbers in villages with high arsenic levels as opposed to villages with below-standard arsenic levels.

The results of this study revealed the fact that circulatory system diseases were the primary cause of death in the area, which was consistent with national and international distribution of causes of death. ${ }^{20-23}$ According to WHO data, ${ }^{21}$ $30.5 \%$ of all deaths in 2008 were due to cardiovascular diseases, which were followed by infectious diseases $(15.3 \%)$ and cancers $(13.3 \%)$. When national causes of death at age 5 and above were analyzed from 2008 data of Turkish Statistical Institute, it was found that heart and cerebrovascular diseases were dominant, with a ratio of $50.4 \%$, and cancers were second most important cause of death, with a ratio of $16.4 \%{ }^{20}$ Based on the data obtained from the hospital death records of 2010 from the Ministry of Health, circulatory system diseases (I00-I99) have the highest percentage of occurrences nationwide with $33.5 \%$, followed by cancers (C00-D48) with $14.8 \% .^{20,22}$ On the contrary, 2008 data from Kütahya Province Department of Health $^{23}$ reveal that $52.5 \%$ of all deaths in Kütahya Province occurred due to heart and cerebrovascular diseases, followed by respiratory system diseases $(8.5 \%)$ and gastrointestinal and respiratory system cancers $(7.9 \%)$. Consequently, circulatory system diseases are among the most predominant cause of death on global, national, and local scales, which is also verified by the results of this study. However, cancers are the third most predominant cause of death after infectious diseases on global scale, whereas they are second on national scale. On a local provincial scale, cancers are the third predominant cause of death after respiratory system diseases. In this study, however, cancer-related deaths ranked second place. 

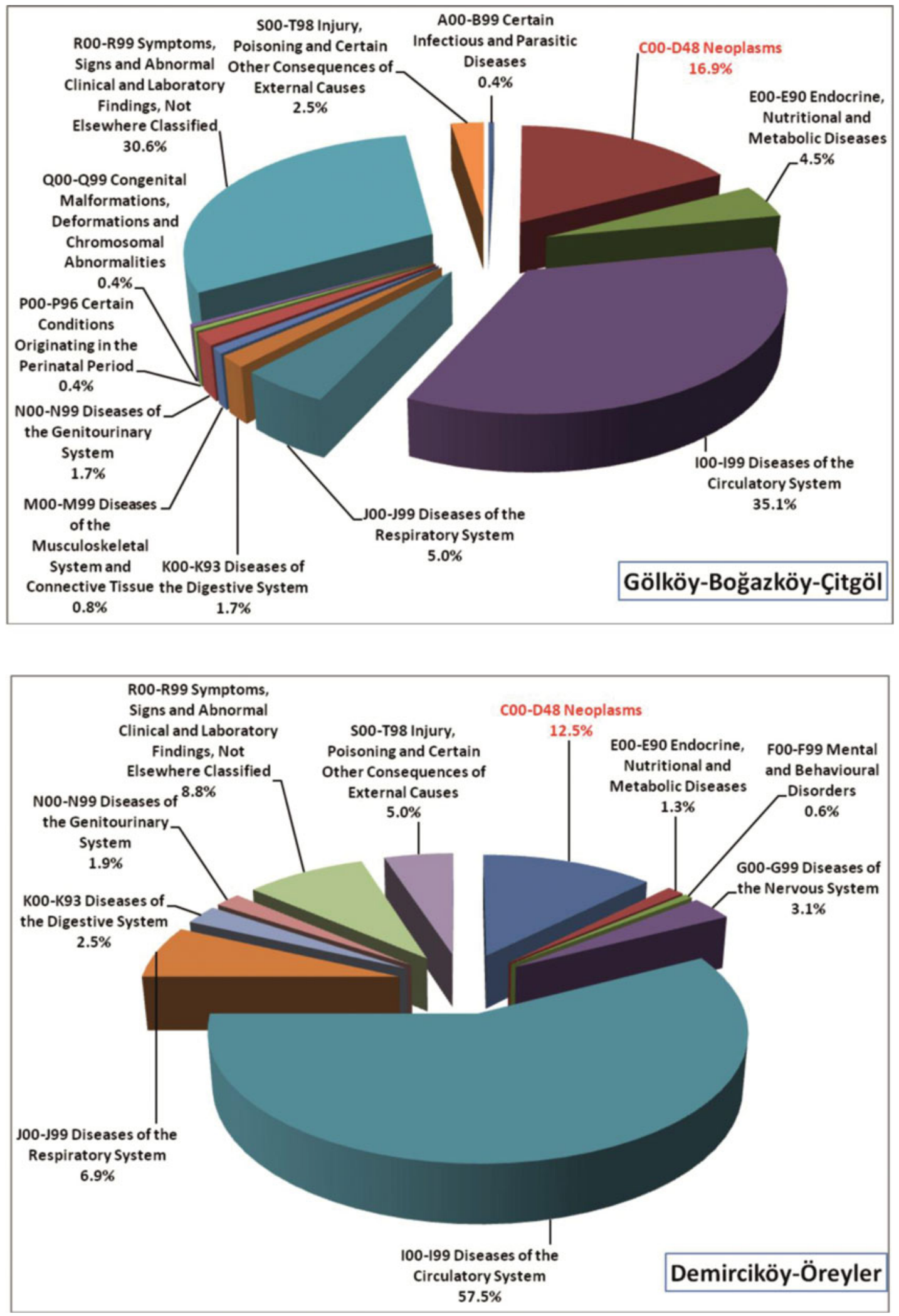

Fig. 2. Distribution of primary cause of death in villages studied, 2011, Simav-Kütahya. 
Table 4. Distribution of Cancer-Related Mortality Causes With Respect To Sex in Villages Studied, 2011, Simav-Kütahya

\begin{tabular}{|c|c|c|c|c|c|c|c|c|c|c|c|c|c|}
\hline \multirow[b]{2}{*}{ ICD-10 code } & \multirow[b]{2}{*}{ Cancer type-Men } & \multicolumn{2}{|c|}{ Total } & \multicolumn{2}{|c|}{ Gölköy } & \multicolumn{2}{|c|}{ Boğazköy } & \multicolumn{2}{|c|}{ Öreyler } & \multicolumn{2}{|c|}{ Demirciköy } & \multicolumn{2}{|c|}{ Çitgöl } \\
\hline & & $n$ & $\%$ & $n$ & $\%$ & $n$ & $\%$ & $n$ & $\%$ & $n$ & $\%$ & $n$ & $\%$ \\
\hline $\mathrm{C} 34$ & $\begin{array}{l}\text { Malignant neoplasm of } \\
\text { bronchus and lung }\end{array}$ & 24 & 52.2 & 3 & 50.0 & 2 & 22.2 & 7 & 100.0 & 6 & 85.7 & 6 & 35.3 \\
\hline C61 & $\begin{array}{l}\text { Malignant neoplasm of } \\
\text { prostate }\end{array}$ & 6 & 13.0 & 1 & 16.7 & 4 & 44.4 & - & - & - & - & 1 & 5.9 \\
\hline $\mathrm{C} 16$ & $\begin{array}{l}\text { Malignant neoplasm of } \\
\text { stomach }\end{array}$ & 5 & 10.9 & - & - & - & - & - & - & - & - & 5 & 29.4 \\
\hline $\mathrm{C} 18$ & Malignant neoplasm of colon & 2 & 4.3 & 1 & 16.7 & - & - & - & - & 1 & 14.3 & - & - \\
\hline $\mathrm{C} 22$ & $\begin{array}{l}\text { Malignant neoplasm of liver } \\
\text { and intrahepatic bile ducts }\end{array}$ & 2 & 4.3 & - & - & 1 & 11.1 & - & - & - & - & 1 & 5.9 \\
\hline C71 & Malignant neoplasm of brain & 2 & 4.3 & - & - & 1 & 11.1 & - & - & - & - & 1 & 5.9 \\
\hline C67 & $\begin{array}{l}\text { Malignant neoplasm of } \\
\text { bladder }\end{array}$ & 2 & 4.3 & - & - & - & - & - & - & - & - & 2 & 11.8 \\
\hline C95 & $\begin{array}{l}\text { Leukemia of unspecified cell } \\
\text { type }\end{array}$ & 1 & 2.2 & - & - & 1 & 11.1 & - & - & - & - & - & - \\
\hline C77 & $\begin{array}{l}\text { Secondary and unspecified } \\
\text { malignant neoplasm of } \\
\text { lymph nodes }\end{array}$ & 1 & 2.2 & 1 & 16.7 & - & - & - & - & - & - & - & - \\
\hline \multirow[t]{3}{*}{ C90.0 } & $\begin{array}{l}\text { Multiple myeloma and } \\
\text { malignant plasma cell } \\
\text { neoplasms }\end{array}$ & 1 & 2.2 & - & - & - & - & - & - & - & - & 1 & 5.9 \\
\hline & Total & 46 & 100.0 & 6 & 13.0 & 9 & 19.6 & 7 & 15.2 & 7 & 15.2 & 17 & 37.0 \\
\hline & Cancer type-Women & & & & & & & & & & & & \\
\hline $\mathrm{C} 18$ & Malignant neoplasm of colon & 4 & 26.7 & - & - & 1 & 33.3 & 2 & 33.3 & & & 1 & 25.0 \\
\hline $\mathrm{C} 34$ & $\begin{array}{l}\text { Malignant neoplasm of } \\
\text { bronchus and lung }\end{array}$ & 3 & 20.0 & 1 & 50.0 & 1 & 33.3 & - & - & - & - & 1 & 25.0 \\
\hline C56 & Malignant neoplasm of ovary & 2 & 13.3 & - & - & - & - & 1 & 16.7 & 1 & 100.0 & - & - \\
\hline $\mathrm{C} 22$ & $\begin{array}{l}\text { Malignant neoplasm of liver } \\
\text { and intrahepatic bile ducts }\end{array}$ & 2 & 13.3 & 1 & 50.0 & - & - & 1 & 16.7 & - & - & - & - \\
\hline $\mathrm{C} 50$ & $\begin{array}{l}\text { Malignant neoplasm of } \\
\text { breast }\end{array}$ & 2 & 13.3 & - & - & - & - & - & - & - & - & 2 & 50.0 \\
\hline C95 & $\begin{array}{l}\text { Leukemia of unspecified cell } \\
\text { type }\end{array}$ & 1 & 6.7 & - & - & 1 & 33.3 & - & 0.0 & - & - & - & - \\
\hline \multirow[t]{2}{*}{$\mathrm{C} 25$} & $\begin{array}{l}\text { Malignant neoplasm of } \\
\text { pancreas }\end{array}$ & 1 & 6.7 & - & - & - & - & 1 & 16.7 & - & - & - & - \\
\hline & Total & 15 & 100.0 & 2 & 13.3 & 3 & 20.0 & 5 & 33.3 & 1 & 6.7 & 4 & 26.7 \\
\hline
\end{tabular}

A similar distribution was found when the causes of death were analyzed with respect to the presence of arsenic in drinking water supplies. For villages with high arsenic levels in drinking water supplies, the primary causes of death were diseases of circulatory system $(35.1 \%)$ and cancers $(16.9 \%)$, respectively. Although the primary causes of death for villages with arsenic concentrations below standard levels were the same, the relative percentages of occurrences changed to $57.5 \%$ for diseases of circulatory system and $12.5 \%$ for cancers (Table 3 and Figure 2).

In general, lung cancer was found to be the most predominant cancer type that resulted in deaths in this study, which was followed by prostate and colon cancers. In men, the most predominant cancer type was determined to be lung cancer, followed by prostate cancer (Table 4). In women, on the other hand, the most fatal cancer type was found to be colon cancer, followed by lung, breast, and ovary cancers (Table 4). The cancer-related mortality rates were found to be 177.4/100,000 as crude mortality rate and 104/100,000 as age-standardized mortality rate calculated based on standard world population. Age-standardized cancer mortality rate was $117.6 / 100,000$ for villages with high arsenic levels and 83.5/100,000 for villages with below-standard arsenic levels (Table 5).

A total of $39.4 \%$ of all cancer-related deaths had a definite history of cigarette smoking. In an additional $31.1 \%$ of all cancer-related deaths, cigarette use could not be identified clearly. Furthermore, it has been found that there is a definite history of cigarette smoking in 51.8\% (14 cases) of all lung cancer-related deaths and a skeptical history in an additional $29.6 \%$ (8 cases). Statistically significant relevance $(p<.05)$ has been detected between cigarette smoking and cancer-related deaths. Whereas $36.4 \%$ of cigarette smokers died as a result of cancer, only $17.1 \%$ of nonsmokers died from cancers. Statistically significant differences $(p<.05)$ were found between 
Table 5. Distribution of Cancer-Related Mortality Rates in Villages Studied, 2011, Simav-Kütahya

\begin{tabular}{|c|c|c|c|c|c|c|c|c|c|c|}
\hline \multirow[b]{2}{*}{ ICD-10 codes } & \multirow[b]{2}{*}{ Cancer type } & \multicolumn{3}{|c|}{ Total } & \multicolumn{3}{|c|}{$\begin{array}{l}\text { Gölköy, Boğazköy, } \\
\text { Çitgöl }\end{array}$} & \multicolumn{3}{|c|}{ Demirciköy, Öreyler } \\
\hline & & $n$ & CMR & $\overline{\mathrm{ASR}}$ & $\bar{n}$ & CMR & $\overline{\mathrm{ASR}}$ & $n$ & CMR & $\overline{\mathrm{ASR}}$ \\
\hline $\mathrm{C} 34$ & $\begin{array}{l}\text { Malignant neoplasm of bronchus } \\
\text { and lung }\end{array}$ & 27 & 78.5 & 50.6 & 14 & 62.6 & 43.4 & 13 & 108.0 & 63.6 \\
\hline C61 & Malignant neoplasm of prostate & 6 & 17.4 & 8.3 & 6 & 26.8 & 15.1 & 0 & 0.0 & 0.0 \\
\hline $\mathrm{C} 18$ & Malignant neoplasm of colon & 6 & 17.4 & 8.3 & 3 & 13.4 & 7.6 & 3 & 24.9 & 9.3 \\
\hline $\mathrm{C} 16$ & Malignant neoplasm of stomach & 5 & 14.5 & 10.6 & 5 & 22.4 & 16.9 & 0 & 0.0 & 0.0 \\
\hline $\mathrm{C} 22$ & $\begin{array}{l}\text { Malignant neoplasm of liver and } \\
\text { intrahepatic bile ducts }\end{array}$ & 4 & 11.6 & 5.6 & 3 & 13.4 & 7.6 & 1 & 8.3 & 3.1 \\
\hline C67 & Malignant neoplasm of bladder & 2 & 5.8 & 2.8 & 2 & 8.9 & 5.0 & 0 & 0.0 & 0.0 \\
\hline C95 & Leukemia of unspecified cell type & 2 & 5.8 & 3.1 & 2 & 8.9 & 5.4 & 0 & 0.0 & 0.0 \\
\hline C71 & Malignant neoplasm of brain & 2 & 5.8 & 2.8 & 2 & 8.9 & 5.0 & 0 & 0.0 & 0.0 \\
\hline C56 & Malignant neoplasm of ovary & 2 & 5.8 & 3.2 & 0 & 0.0 & 0.0 & 2 & 16.6 & 3.1 \\
\hline $\mathrm{C} 50$ & Malignant neoplasm of breast & 2 & 5.8 & 4.1 & 2 & 8.9 & 6.4 & 0 & 0.0 & 0.0 \\
\hline C77 & $\begin{array}{l}\text { Secondary and unspecified } \\
\text { malignant neoplasm of lymph } \\
\text { nodes }\end{array}$ & 1 & 2.9 & 1.4 & 1 & 4.5 & 2.5 & 0 & 0.0 & 0.0 \\
\hline C90 & $\begin{array}{l}\text { Multiple myeloma and malignant } \\
\text { plasma cell neoplasms }\end{array}$ & 1 & 2.9 & 1.4 & 1 & 4.5 & 2.5 & 0 & 0.0 & 0.0 \\
\hline \multirow[t]{2}{*}{$\mathrm{C} 25$} & Malignant neoplasm of pancreas & 1 & 2.9 & 1.8 & 0 & 0.0 & 0.0 & 1 & 8.3 & 4.4 \\
\hline & Total & 61 & 177.4 & 104.0 & 41 & 183.4 & 117.6 & 20 & 166.1 & 83.5 \\
\hline
\end{tabular}

Note. $\mathrm{CMR}=$ crude mortality rate (per 100,000); ASR = age-standardized incidence ratios. World standard population (per 100,000).

cigarette smoking and cancer occurrences. Furthermore, lung cancer was found to be the cause of death in $21.2 \%$ of all smokers and only $4.8 \%$ of nonsmokers. On the other hand, no statistically significant differences $(p>.05)$ were detected between cancer-related deaths and alcohol use.

\section{Comment}

As a result of extended life expectancy, prevention of premature deaths, and increased exposure to environmental risk factors, number of deaths due to chronic diseases and cancers increase globally. In this regard, smoking is considered to be the predominant risk factor for these diseases. In this study, statistically significant correlation was detected between smoking and cancer-related deaths in the study area. Environmental risk factors such as heavy metal contents in drinking water also play an important role in the occurrences of chronic diseases and cancers. Although some of these factors are anthropogenic, many could be the result of natural processes and are typically geogenic in nature.

Arsenic is considered to be among these geogenic environmental risk factors and has been proven to create significant health risks. ${ }^{2-4,6,7}$ Epidemiological studies have shown that exposure to high arsenic levels $(>300 \mu \mathrm{g} / \mathrm{L})$ in groundwater is a typical risk factor for cardiovascular diseases and mortality related to hypertension, atherosclerosis, ischemic heart diseases, diabetes mellitus, and vascular diseases. ${ }^{3,6,7,24}$ In particular, Rahman et $\mathrm{al}^{3}$ has shown that diabetes mellitus risk adjusted for age, gender, and body mass index were 5.9 times higher
(95\% confidence interval: $2.5-7.7$ ) in areas with arsenic exposure from drinking water. Similarly, Wang et $\mathrm{al}^{25}$ have shown that deadly metabolic syndrome (ie, coexistence of cardiovascular diseases, obesity, dyslipidemia, and diabetes mellitus) risk adjusted for age, gender, occupation, and lifestyle including cigarette smoking was 2.54 times higher $(95 \%$ confidence interval: $1.20-5.39)$ in an arsenic-exposed population.

Arsenic could also result in pigmentation, hypercreatosis, and other complications that could lead to cancer in skin. ${ }^{7}$ In a study conducted in Bangladesh, Argos et $\mathrm{al}^{26}$ have shown that premalignant skin lesions have a dose-dependent correlation with arsenic exposure. In a study conducted in Emet District of Kütahya, Turkey, skin lesions were detected in $30.9 \%$ of the total population in the village of İgdeköy with very high arsenic concentrations in drinking water supply $(8.9-9.3 \mathrm{mg} / \mathrm{L})$, whereas it was observed only in $5.35 \%$ of total population in the village of Dulkadir with comparably lower arsenic levels in drinking water supply. In Emet area, the most predominant skin lesions were palmoplantar keratosis, basal cell carcinoma, plantar keratoderma, and plantar hyperkeratosis. ${ }^{12}$ Such high arsenic levels in drinking water supplies in Emet area are identified to be the main reason for the high number of occurrences of skin lesions. Although Emet was in close proximity to this study area, the arsenic levels were significantly lower, which explains the reason for not finding as many skin cancer cases in the study area as in Emet.

The most important consequence of arsenic exposure from drinking water on human health is cancers. Numerous epidemiological researches have shown arsenic-related increased cancer risk and mortality in humans. ${ }^{2}$ Among these cancers, 
the most significant ones are cancers of skin, lung, liver, bladder, and gastrointestinal tract. ${ }^{7}$ In a study conducted in Argentina, correlations between high arsenic levels and lung, bladder, and colon cancers in females were found. ${ }^{27}$ In another study conducted in Taiwan, it was found out that lung and bladder cancer risks increased 2.27 (95\% confidence interval: $1.44-3.58)$ and 7.80 (95\% confidence interval: 2.64-23.1) times, respectively, in cases where arsenic levels exceed $300 \mu \mathrm{g} / \mathrm{L}$ in water. ${ }^{28}$ Moreover, Çelik et al ${ }^{29}$ have shown a correlation between arsenic levels and cancer incidence and mortality in their systematic review on arsenic in drinking water supply and lung cancer. Similarly, Marshall et $\mathrm{al}^{30}$ have also reported that arsenic increases the mortality risks from lung and bladder cancers.

In this study, cancer-related mortality ranked second place among all cases of death. Cancer-related mortality was found in high percentages in area with high arsenic concentrations, whereas circulatory system-related mortality dominated the villages with below-standard arsenic concentrations. Cancerrelated age-standardized mortality rate was calculated to be higher in villages with high arsenic levels. When cause-related mortality rates were analyzed, it was observed that all cancer types, excluding lung, colon, ovarian, and pancreas cancers, were found to be higher in villages with high arsenic levels (Table 5). However, cigarette smoking is a confounding factor for lung cancer occurrences. Despite the fact that no significant deviations between villages were found in the percentage of smoking population, $30 \%$ of deceased had a history of smoking. Furthermore, high cigarette consumption in individuals with lung cancer was believed to be one of the reasons for this situation. Nevertheless, it must be noted that 4 of 5 death cases with no smoking history were seen in villages with high arsenic concentrations in drinking water supply. Although there are no statistical data that could support the cause-and-effect relation of this phenomena, this finding is still valuable considering the literature data as well as the fact that only very few cases of lung cancer could be obtained in a relatively small population.

Deaths related to colon cancer were found to be the same in both groups of villages with low and high arsenic levels. Only 1 case of death from pancreas cancer was found in high arsenic area. Furthermore, all other deaths from other cancer types were dominant in high arsenic area. In essence, all cases of bladder and stomach cancers and the majority of liver cancer cases were found in villages with high arsenic concentrations in drinking water supply, which implies the presence of high risk in these villages associated with high exposure, since no other differences were observed between the villages that could influence the cancer-related mortality rates. The villagers of Gölköy, Boğazköy, and Çitgöl have consumed high arsenic-laden drinking waters for over 20 years. Although no data exist beyond 20 years, it is likely that these villages have used similar water resources with high arsenic levels. Considering this long duration of exposure to high arsenic levels, it is not surprising to find health-related problems in the exposed population. The primary reason for not discovering this phenomenon earlier is mainly related to the lack of robust health records. It is important to note that only $24.6 \%$ of all deaths occurred in a hospital and only 22 took place in local Simav
State Hospital. Of these 22 cases, the records of 15 cases were accessed and compared with the results of verbal autopsy. In $12(80 \%)$ of these cases, the causes of death taken from hospital records were consistent with the results obtained from the verbal autopsy.

Causes of death in rural areas in Turkey are rarely documented properly unless the event took place in a hospital. Even in hospital conditions, the doctors in charge could sometimes behave inconsiderately and do not document the actual cause of death correctly. This situation makes it hard to detect and analyze the mortality data in the country, which was one of the reasons for implementing a verbal autopsy survey to reach the actual cause of death in this study.

In addition to direct exposure through drinking water, the population can also be indirectly exposed to arsenic through consumption of arsenic-laden agricultural products. It was previously reported that agricultural products irrigated with arsenic-containing water could contain significant amounts of arsenic. In a study conducted in India, Roychowdhury et $\mathrm{al}^{31}$ has determined that arsenic was absorbed by the skin of most vegetables. Their results further revealed that the individual food composite and food groups containing the highest mean arsenic concentrations $(\mathrm{mg} / \mathrm{kg})$ were potato skin (292.62 and 104), leaf of vegetables (212.34 and 294.67), arum leaf (331 and 341), papaya (196.50 and 373), rice (226.18 and 245.39), wheat (7 and 362), cumin (47.86 and 209.75), turmeric powder (297.33 and 280.9), cereals and bakery goods (156.37 and 294.47), vegetables (91.73 and 123.22), and spices (92.22 and 207.60) for 2 areas of West Bengal, India, respectively. In this context, edible crops grown in the study area are mostly irrigated with arsenic-containing groundwater and are most likely to be a second route of exposure for local inhabitants.

\section{Conclusions and Recommendations}

A comparative analysis of causes of death in an arsenicexposed population and a control population pointed out the fact that the cases of death from certain diseases that occurred in arsenic-exposed population were higher in number. Although the results of this study did not clearly reflected a direct arsenic-cancer relationship, comparably higher cancerrelated death cases were detected in villages with high arsenic in drinking water supply. In particular, some cancer types (ie, stomach and bladder) were only detected in villages with high arsenic levels. More concrete correlations are only possible with minimum 10-year follow-up monitoring studies.

Despite the uncertainties associated with defining direct correlations between arsenic exposure and cancer (excluding the globally accepted case of skin cancer), this study demonstrated not only a systematic methodology in assessing the public health concerns of arsenic exposure under data-limited field conditions but also helped local inhabitants to achieve improved life standards with regards to access to arsenic-free drinking water. In this particular case, this improvement was achieved through stopping the exposure by finding an alternative water resource in 2 villages (Gölköy and Boğazköy) and by implementing an advanced arsenic treatment plant in 
the other village (Çitgöl) as a consequence of the studies conducted in the study area.

However, minimizing the exposure risk through drinking water is not enough to completely eliminate the health risks associated with arsenic exposure. Considering the presence of other possible routes of exposure, further research is deemed necessary to quantify the presence of arsenic in certain agricultural products, such as sunflower seed, bean, tomato, and sugar beet that are common to the area and are irrigated with arsenic-contaminated waters and in animal products such as milk and meat of animals that consumed arseniccontaminated waters in the field. Reducing the exposure risks from food chain would help the local population avoid another route of exposure and minimize arsenic-related health problems in the area.

Finally, continuous monitoring of the quality of local drinking water resources should be provided with particular reference to arsenic and its species. Such a monitoring activity would help local administrators quantify all possible risks associated with arsenic exposure and would prevent the occurrences of many diseases, including but not limited to cancer. These preventive measures would reduce the overall costs of treating such diseases.

\section{Acknowledgments}

The authors express their gratitude to the local administrators of the villages of Çitgöl, Boğazköy, Gölköy, Demirciköy, and Öreyler for their support during field work.

\section{Funding}

This study was funded by the Scientific and Technological Research Council of Turkey (TÜBİTAK) through project number 109Y029.

\section{References}

1. Tapio S, Grosche B. Arsenic in the aetiology of cancer. Mutat Res. 2006;612:215-246.

2. International Agency for Research on Cancer (IARC). IARC Monographs on the Evaluation of Carcinogenic Risks to Humans, Volume 84: Some Drinking-Water Disinfectants and Contaminants Including Arsenic. Lyon: World Health Organization International Agency for Research on Cancer; 2004.

3. Rahman M, Tondel M, Ahmad SA, Axelson O. Diabetes mellitus associated with arsenic exposure in Bangladesh. Am J Epidemiol. 1998;148:198-203.

4. Selene CH, Chou J, De Rosa CT. Case studies-arsenic. Int J Hyg Environ Health. 2003;206:381-386.

5. Meliker JR, Wahl RL, Cameron LL, Nriagu JO. Arsenic in drinking water and cerebrovascular disease, diabetes mellitus, and kidney disease in Michigan: a standardized mortality ratio analysis. Environ Health. 2007;6:4. Available at: http://www. biomedcentral.com/content/pdf/1476-069x-6-4.pdf.

6. States JC, Srivastava S, Chen Y, Barchowsky A. Arsenic and cardiovascular disease. Toxicol Sci. 2009;107:312-323.
7. Hughes MF, Beck BD, Chen Y, Lewis A, Thomas DJ. Arsenic exposure and toxicology: a historical perspective. Toxicol Sci. 2011;123:305-332.

8. Jovanovic D, Rasic-Milutinovic Z, Paunovic K, Jakovljevic B, PlavsicS, Milosevic J. Low levels of arsenic in drinking water and type 2 diabetes in Middle Banat region, Serbia. Int J Environ Health. 2012;216:50-55.

9. World Health Organization. Guidelines for Drinking Water Quality Third Edition. Vol. 1. Geneva: World Health Organization; 2004.

10. US Environmental Protection Agency. National Primary Drinking Water Standards. Washington, DC: US Environmental Protection Agency Office of Water; 2003.

11. Ministry of Evironment and Forestry. Regulation on Waters Intended for Human Consumption (ITASHY) [Turkish]. Published 17 February 2005, No. 25730. Ankara: Turkish Official Gazette; 2005.

12. Doğan M, Doğan AU, Çelebi C, Barış YI. Geogenic arsenic and a survey of skin lesions in the Emet Region of Kütahya, Turkey. Indoor Built Environ. 2005;14:533-536.

13. Gunduz O, Simsek C, Hasozbek A. Arsenic pollution in the groundwater of Simav Plain, Turkey: its impact on water quality and human health. Water Air Soil Pollut. 2010;205:43-62.

14. Baba A, Tayfur G. Groundwater contamination and its effect on health in Turkey. Environ Monit Assess. 2011;183:77-94.

15. Simsek C, Gunduz O. IWQ index: a GIS-integrated technique to assess irrigation water quality. Environ Monit Assess. 2007;128:277-300.

16. Gunduz O, Elci A, Simsek C, et al. Final Report [Turkish]. TUBITAK Project No. 109Y029. Izmir, Turkey: The Scientific and Technological Research Council of Turkey; 2012.

17. Barbalace K. Periodic Table of Elements. Available at: http:// environmentalchemistry.com/yogi/periodic/. Accessed June 1, 2013.

18. Lemeshow S, Hosmer DW Jr, Klar J, Lwanga SK. Adequacy of Sample Size in Health Studies. West Sussex: John Wiley and Sons; 1990.

19. Refik Saydam Hygiene Centre Presidency. National Burden of Disease and Cost Effectiveness Project (NBoD) Verbal Autopsy Interim Report. Ankara: Ministry of Health, Refik Saydam Hygiene Centre Presidency, School of Public Health; 2004.

20. Turkish Statistical Institute. Death Statistics of Province and District Centers in 2008. Ankara: Turkish Statistical Institute; 2009.

21. World Health Organization. Global Health Observatory Data Repository. Causes of Death 2008 Summary Tables. Geneva: World Health Organization Department of Health Statistics and Informatics; 2008. Available at: http://www.who.int/evidence/bod. Accessed November 15, 2011.

22. Mollahaliloglu S, Basara BB, Eryılmaz Z. Health Statistics Yearbook 2010. Ankara: School of Public Health, Refik Saydam Hygiene Center Presidency, Ministry of Health of Turkey; 2011.

23. Kütahya Department of Health. Health Statistics Yearbook of 2008 [Turkish]. Kütahya: Kütahya Department of Health; 2009. Available at: http://www.Kütahyasaglik.gov.tr/index.php?opt= detay\&id=29. Accessed November 15, 2011.

24. Chen CJ. Health hazards of arsenic in drinking water. In: Jean JS, Bundschup J, Bhattacharya P, eds. Arsenic in Geosphere and Human Diseases: Arsenic in the Environment (As 2010); Tainan, Taiwan; May 17-21, 2010; London UK: CRC Press; 2010:251-253.

25. Wang SL, Liou SH, Wang HJ, Li WF, Chang FH. Arsenic and metabolic syndrome. In: Jean JS, Bundschup J, Bhattacharya P, eds. Arsenic in Geosphere and Human Diseases: Arsenic in the Environment (As 2010); Tainan, Taiwan; May 17-21, 2010; London UK: CRC Press; 2010:254-255.

26. Argos M, Parvez F, Chen Y, et al. Socioeconomic status and risk for arsenic-related skin lesions in Bangladesh. Am J Public Health. 2007;97:825-931.

27. Aballay LR, Diaz MP, Francisca, FM, Mufloz SE. Cancer incidence and pattern of arsenic concentration in drinking water wells in Cordoba, Argentina. Int J Environ Health Res. 2011;22:220-231. 
28. Chen CL, Chiou HY, Chen CJ. Ingested arsenic and risk of urinary and lung cancer in Taiwan. In: Jean JS, Bundschup J, Bhattacharya $\mathrm{P}$, eds. Arsenic in Geosphere and Human Diseases: Arsenic in the Environment (As 2010); Tainan, Taiwan; May 17-21, 2010; London UK: CRC Press; 2010:275-277.

29. Çelik I, Gallicchio L, Matanoski G, et al. Arsenic in drinking water and lung cancer: a systematic review. Environ Res. 2008;108:48-55.
30. Marshall G, Ferreccio C, Yuan Y, et al. Fifty-year study of lung and bladder cancer mortality in Chile related to arsenic in drinking water. J Natl Cancer Inst. 2007;99:920-928.

31. Roychowdhury $T$, Uchino $T$, Tokunaga $H$, Ando M. Survey of arsenic in food composites from an arsenic-affected area of West Bengal, India. Food Chem Toxicol. 2002;40:16111621. 